DOI: 10.30519/ahtr.693400

Advances in Hospitality and Tourism Research (AHTR)

\title{
DOES MUSEUM MARKETING MEET POSTMODERN CONDITIONS?
}

\author{
Seda SÖKMEN ${ }^{1}$ \\ Department of Tourism Management, Anadolu University, Turkey \\ ORCID: 0000-0003-3793-9145 \\ Medet YOLAL \\ Department of Tour Guiding, Anadolu University, Turkey \\ ORCID: 0000-0002-9834-2425 \\ Çağıl Hale ÖZEL \\ Department of Tourism Management, Anadolu University, Turkey \\ ORCID: 0000-0002-4898-0867
}

\begin{abstract}
The purpose of this study is to explore how museum marketing meets postmodern conditions. Based on a sample of 12 museums in Istanbul, Turkey, a qualitative study was conducted to evaluate whether museum marketing meets the five conditions of postmodernism, namely decentered subject, reversal of production and consumption, fragmentation, juxtaposition of opposites and hyperreality. The findings of this study reveal that the marketing practices of museums meet all conditions of postmodernism except that of the decentered subject. They also demonstrate that museum managers hold negative attitudes towards the decentered subject, mainly due to their resistance to intermediaries between the exhibition and the audience.
\end{abstract}

\section{Article History}

Received 24 February 2020

Revised 15 September 2020

Accepted 23 September 2020

\section{Keywords}

Postmodern conditions

Marketing

Museums

Istanbul

\footnotetext{
1 Address correspondence to Seda SÖKMEN, Department of Tourism Management, Faculty of Tourism, Anadolu University, Eskișehir, TURKEY. E-mail: sedasokmen@anadolu.edu.tr
} 


\section{INTRODUCTION}

Museums originate from the need to acquire, conserve, research, communicate and exhibit material evidence of human beings and the environment for the benefit of the public. Their mission has been explained in detail by the International Council of Museums (ICOM):

Museums are democratizing, inclusive and polyphonic spaces for critical dialogue about the pasts and the futures. Acknowledging and addressing the conflicts and challenges of the present, they hold artefacts and specimens in trust for society, safeguard diverse memories for future generations and guarantee equal rights and equal access to heritage for all people. Museums are not for profit. They are participatory and transparent, and work in active partnership with and for diverse communities to collect, preserve, research, interpret, exhibit, and enhance understandings of the world, aiming to contribute to human dignity and social justice, global equality and planetary wellbeing (2019).

In accordance with this definition, it has been suggested that museums exist to provide an authentic experience rather than act as agents of conservation, as in other contemporary cultural institutions. Over the course of time, the role of museums has expanded from uncovering our past to providing a space for a variety of learning, engagement and entertainment experiences (Chhabra, 2008). This restructuring of museums raises important questions about not only the traditional public mandate of museums but their ability to enhance consumption experiences and tourism products as well (Tufts \& Milne, 1999). Therefore, contemporary museums serve increasingly complex institutional missions and diverse audiences through their programs.

One of the drivers of changes in the role and mission of museums is postmodernism's position as a battlefield of contradictory ideas. In an era that necessitates alterations in the construction and formation of museums, many debates surround the physical space of museums, museum collections, accessibility and audience development (Barrett, 2011). As they re-evaluate themselves within this framework, museums have begun to redesign their objectives, philosophies, applications and performance in light of cultural and social developments (Hooper-Greenhill, 2007). As such, museums influenced by postmodernism are labelled as postmodern museums (Huyssen, 1995). Postmodern museums are malleable, plastic spaces that can easily be reshaped (Kahraman, 2015). Similarly, Urry (2002) suggests that the age of absolute silence in museums is over, and 'dead' museums are transformed into living places by eliminating windows 
between exhibits and museums. Foucault and Miskowiec (1986) claim that museums are heterotopias that colligate and exhibit various cultures in real spaces, unlike utopias of the modern era. Postmodern museums revolve around notions of populism, communication, interaction, democratisation, cultural diversity, participation and accessibility, abandoning traditional displays while focusing on active visitor participation and offering simulations rather than unique authenticity (Brown, 1995, p. 74; Stanbridge, 2005, p. 162; Barrett, 2011, p.109).

Museums have attracted the interest of academics, with previous studies having examined their development (Schubert, 2004; Barrett, 2011), their evolving functions in society (Glaser \& Zenetou, 1996), their place as cultural spaces (Message, 2006), their marketing (McLean, 1995; Tobelem, 1997; Kotler et al., 2008) and their visitor management strategies (Scoffield \& Liu, 2014). Studies have also scrutinised the financial problems they have faced (Rentschler, 1998) and their efforts to compete with the leisure and entertainment industries (Davidson \& Simbley, 2011). These studies identify museums as places that can be visited for recreation, shopping, dining and entertainment in addition to education and viewing the collections. Focusing on the variety of resources available to museums, Rentschler and Gilmore (2002) suggest that even the architecture of a museum can be regarded as a product offering. In a similar vein, Giebelhausen (2006) claims that several museums market themselves via their deconstructivist architectural forms and the architects who design them, one example being the Guggenheim Museum Bilbao by Frank Gehry (Kotler et al., 2008, p. 311).

As noted by Tobelem (1997), the increasing involvement of museums in all types of market mechanisms has resulted in an escalating struggle to achieve greater visibility, expand offerings, reach a broader audience and raise income in order to survive and surpass the competition (Kotler \& Kotler, 2000), not only with other museums but with alternative providers of leisure and educational activities as well. In addition, rapid changes in society and the surrounding environment have also forced museums to define their positions accordingly and adapt to changes in the marketplace (Prentice, 2001).

In the contemporary era, consumers emphasise form and style when determining the meaning of life and navigating disorder and chaos (Firat \& Schultz, 1997). These tendencies of postmodern consumers require postmodern museums to develop more effective ways of reaching their audiences. Consequently, museums have evaluated their audiences and 
employed strategies to meet their changing expectations, such as creating active roles for audience members (Pulh et al., 2008), displaying innovative and entertaining exhibits (Heath \& VomLehn, 2008) that are socially interactive (Jafari et al., 2013) and encouraging the use of digital technologies (Drotner \& Schrøder, 2013). Although postmodern conditions have the potential to enrich the museum experience, there has been little research as to whether museums use these conditions in order to tailor their offerings towards meeting the changing consumer expectations and demand (Taheri et al., 2016). Therefore, the purpose of the current study is to holistically explore how museum marketing meets postmodern conditions in the case of Istanbul, Turkey.

The findings of this study are likely to contribute significantly to museum theory and practice by furthering our understanding of postmodern museums and their marketing. While a large number of studies have examined museum marketing and postmodern marketing separately (e.g. Heath \& VomLehn, 2008; Pulh \& Mencarelli, 2015), museum marketing through the lens of postmodern conditions has not received much attention. Although the postmodern conditions are handled separately, a holistic perspective could not be presented (Taheri et al., 2016). This study will fill this research gap primarily by focusing on the postmodern conditions employed by or influencing museums. Examining the postmodern marketing of museums will enable us to better comprehend the postmodern museum experience. Furthermore, the results of the study are expected to help museums navigate postmodern conditions in order to gain a competitive edge in the marketplace.

\section{POSTMODERN CONDITIONS IN MARKETING}

Postmodernism is an important concept that has been examined in the humanities, architecture, literature and related areas (Brown, 1993; Van Raaij, 1993; Amine \& Smith, 2009). As postmodern ideas and conceptions have been applied to a variety of disciplines, interpretations and conceptualisations of postmodernism have also diversified (Featherstone, 2007; Ward, 2014). In this regard, postmodernism is an umbrella term describing a set of ideas that can be used to define and explain trends in society (Ward, 2014). As such, it is recommended to posit postmodernism as a series of concepts and debates rather than simplifying it to a single, reductive, universal definition. 
Within the literature, there are two main perspectives on postmodernism (Rosenau, 1991; Firat \& Venkatesh, 1996; Odabasi, 2014): as a chronological, historical period and as a temporary trend or psychological state. Moreover, debate persists as to whether postmodernism is the result of a rupture from an earlier epoch in an eternal cycle of change or simply another dimension of the modern era (Harvey, 1991; Ward, 2014). Therefore, postmodernism can be examined in several ways, including as a counter-stance to the modernist world - a movement that questions the modern - an ideology against ideologies, a way of thought, an art movement or art phenomenon and a trend apart from postmodernism itself (Doltas, 2003).

Postmodernism has also been applied in business, especially in marketing throughout the 1980s and 1990s (Venkatesh et al., 1993; Venkatesh, 1999; Amine \& Smith, 2009). Because postmodernism underlies the frameworks of several marketing models and theories, marketers gain the opportunity to understand the dynamic structures of the market and adapt themselves to its confines (Nooteboom, 1992; Brown, 1993). Hence, postmodern trends in marketing can only be understood via knowledge of postmodern conditions. Initial efforts to identify these conditions were spearheaded by Van Raaij (1993), Brown (1995) and Firat and Venkatesh (1993). Over the course of time, these conditions have been expanded upon and interpreted in different ways. For example, Van Raaij (1993, p. 562) groups these conditions into four dimensions: fragmentation of markets and experiences, hyperreality of products and services, value realisation and paradoxical juxtapositions of opposites. However, leading postmodernism scholars such as Firat, Venkatesh, Dholakia and Shultz focus on five important conditions: hyperreality, fragmentation, reversal of production and consumption, decentered subject and juxtaposition of opposites (Firat, 1991; Firat et al., 1995; Firat \& Venkatesh, 1996; Firat \& Shultz, 1997, 2001; Venkatesh, 1999; Firat \& Dholakia, 2006).

Firat and Shultz (1997) highlight the impacts of postmodern conditions on marketing and formulate suitable marketing strategies for emerging markets. For example, they identify the use of thematisation and simulations in the marketplace as a facet of hyperreality. Theme parks such as Jurassic World and Disneyland, as well as attractions and locations such as Las Vegas, IMAX, the artificial archipelago of Palm Jumeirah in Dubai and themed hotels, are manufactured spaces designed to meet the expectations and preferences of consumers (Firat \& Venkatesh, 1993; Firat \& Shultz, 1997). Fragmentation, on the other hand, is the breaking into parts of a complete, singular reality into multiple realities of life, experience, 
society and, most importantly, meta narratives (Firat \& Venkatesh, 1995; Lyotard, 2013). Firat and Venkatesh (1993) exemplify fragmentation with the case of shopping malls that offer fragmented experiences such as entertainment and interaction alongside shopping opportunities.

Reversal of production and consumption refers to the abandonment of the notion that production creates value and consumers destroy it. Instead, production and consumption occur simultaneously, and suppliers and customers are no longer on opposite sides. An act of production is also an act of consumption and vice versa, which can be termed co-creation (Firat \& Venkatesh, 1995; Ritzer, 2014). Postmodernism views consumers as active producers of the symbols and signs of consumption and casts them as objects in the marketing process, while products become active agents (Ritzer, 2010). Process marketing is recommended in individualised markets as a result of the reversal of production and consumption. Modular smartphones produced by Google's Project Ara are good examples of this condition. Consumers are supplied with cameras, batteries, processors and several other modules based on their needs and wants after buying the case and $\mathrm{Wi}-\mathrm{Fi}$ receivers at a convenient price. Thus, production becomes an everlasting process that continues even after consumption. Similarly, the decentered subject suggests that consumers with multiple identities can be reached through the continuous recreation of images. For example, in the online game Second Life, consumers compose their own three-dimensional characters. By choosing their nicknames and distinct physical appearances, players inhabit a fictional self that is detached from their real, physical self (Hemp, 2006).

The condition juxtapositions of opposites denote that consumption experiences are not meant to reconcile differences and paradoxes but rather allow them to exist freely together. Postmodernism affirms and supports all oppositions (Firat \& Venkatesh, 1993, p. 237-239; Firat \& Dholakia, 2006, p. 130-132), as opposing ideas, styles and cases allow new ideas to flourish. In other words, the concepts of 'order and control' are gradually replaced by the concepts of 'ambiguity and indeterminacy', leading to the creation of irony, ambiguity and, finally, pastiche (Brown, 1993, p. 22).

\section{POSTMODERN MUSEUMS AND THEIR MARKETING}

Given the increasing hegemony of postmodernist thinking over the course of time, twentieth-century debates surrounding museums have concentrated on the physical space of the museum and museum collections, 
access to museums and ways to increase the number of museum visitors (Barrett, 2011). Emerging ideas about culture and society as well as new policy initiatives have challenged museums to rethink their purposes, account for their performance and reformulate their pedagogies (HooperGreenhill, 2007). Scholars attribute these changes to the postmodern era, labelling these museums as 'postmodern museums' (Duclos, 1994; Brown, 1995; Huyssen, 1995; Keene, 2005; Russo \& Watkins, 2005). Although it is difficult to examine postmodern museums within the confines of a single definition (Stanbridge, 2005), postmodern museums are marked by communication, interaction, democratisation, cultural diversity and accessibility; they abandon traditional displays, prioritise active visitor participation and implement simulations (Brown, 1995; Barrett, 2011). More broadly, postmodern museums differ in terms of the types of objects, displays and visitors they cultivate (Urry, 2002).

Museums embraced management culture in the 1980s ( $\mathrm{Wu}, 2014)$. During the 1990s, marketing thought was introduced to museum planning and strategy development (Rentschler, 1998; Scoffiel \& Liu, 2014). According to McLean (1995), only a small number of museums initially adopted marketing strategies, but this number later increased. Tobelem (1997) explains that this increase was due to the necessity of museum development, difficulties in finding funds, intensifying competition within the entertainment sector and museums' willingness to better understand their visitors. Consequently, the idea of museum marketing emerged, and several studies have since examined the marketing practices of museums (Kotler, 2001; Gilmore \& Rentschler, 2002; Belenioti \& Vassiliadis, 2017).

Based on studies by Kotler and Kotler (2000) and Rentschler and Gilmore (2002), one can see that postmodern museum marketing has distinct characteristics. The market segmentation of museum visitors differs from that of traditional marketing. In this regard, Scoffield and Liu (2014) highlight the importance of museum visitors' changing expectations and attitudes and point to the complexity of predicting visitor attitudes in the postmodern era. Efforts to group postmodern individuals under one umbrella may distort marketing targets and strategies for museums (Dawson \& Jensen, 2011). Instead, postmodern museums strive to gather more in-depth intelligence about their visitors and their behaviours (Vicente-Mariño, 2014). Accordingly, most marketing research regarding museums focuses on their visitors (Kasim et al., 2014; Packer \& Ballantyne, 2016). However, researchers of postmodern museums employ different methods when examining visitors' behaviours compared to those of modern museums. In fact, Cerquetti (2016) claims that over the last decade, 
museum visitor studies have increasingly resembled qualitative research. Therefore, postmodern marketers concentrate on the parts of the whole rather than shallow analysis of the impacts that visitors or the group have on the others (Cova \& Cova, 2001).

Postmodern museums are hardly mere spaces housing objects and collections. They have diversified their offerings and market segments via their shopping venues, restaurants and outlets. Consequently, they have become places for both learning and entertainment. Rentschler and Gilmore (2002) also suggest that architecture offers a way for museums to distinguish themselves from others, and it also represents the differentiation of their distribution efforts. Furthermore, as previously mentioned, Giebelhausen (2006) notes that postmodern museums may be able to promote themselves via their deconstructivist architecture and the architects who design them.

Postmodern museum marketing also differs in its use of marketing strategies. In this regard, Komarac et al. (2017) suggest that museums indirectly compete with entertainment businesses such as theme parks, sports, theatres and cinemas. In order to gain a competitive edge, postmodern museums seek to enrich the experiences they offer while surprising their visitors. This can be explicitly observed in flash mob marketing strategies of postmodern museums. Flash mob marketing is defined by Grant et al. (2012, p. 244) as 'groups of people who pre-organize, typically on a social media platform, then assemble in a public place, do something performance oriented, and quickly disperse'. The Rijksmuseum offers a vivid example of flash mob marketing: a group of people in $17^{\text {th }}$ century costumes who appear from different places in a shopping mall, walk through outlets and form Rembrandt's The Night Watch by meeting at a specific point (Artan, 2014). Strategies and practices such as this exemplify the differentiation of postmodern museums' promotional efforts.

Finally, the importance of integrated marketing communication in postmodern museums must be noted as well. Creating a social media presence and posting photos of collections is no longer sufficient for postmodern museums. Similarly, since event lists, reminders and announcements are forms of one-way communication, which has been proved to be ineffective, museums must find ways to construct a platform that offers interactive communication with the public. Therefore, marketing communication experts who are familiar with museum collections are necessary, and attractive, interesting content must be offered via social 
media communications that synthesise collections and actual developments (Baker, 2017).

In order to explain the radical changes occurring in museums, new museology has developed, and thus, museology has become increasingly interdisciplinary. Marketing is only one of the disciplines involved in museology. Marketing practices of modern museums that have adopted business culture have been investigated in literature (Yorke \& Jones, 1984; Rentschler, 1998; Scoffiel \& Liu, 2014). However, the differentiation of marketing practices between modern and postmodern museums has not received the attention it deserves in either the fields of museology or marketing. Therefore, this study investigates whether museums meet the conditions of postmodernism in their marketing, using the case of museums in Istanbul, Turkey as an example.

\section{METHOD}

Qualitative research methods incorporate the systematic collection, organisation and interpretation of textual material derived from interviews and observation (Denzin \& Lincoln, 2005). Therefore, an exploratory approach adopting a qualitative research method using in-depth interviews was decided to be most suitable for the purposes of this study. Private museums were included in the study under the assumption that they behave more independently than state museums in terms of management and marketing. In Turkey, there are 279 private museums, 61 (almost a quarter) of which are in Istanbul. Therefore, Istanbul was selected as the study site due to its rich variety of private museums, collections and services.

This study employed purposive sampling, and postmodern museums in Istanbul were selected as the study sample based on experts' opinions. These experts included researchers who have published research articles on the topics of postmodern marketing, museums and museum professionals. In order to collect their opinions, a link to an online form accessed via Google Forms was sent to the experts between the $3^{\text {rd }}$ and $10^{\text {th }}$ of May 2016. A total of six responses were collected during this period. Experts evaluated museums in Istanbul based on the following features (Cova \& Cova, 2001; Lumley, 2003; Lepouras \& Vassikalis, 2004; Schubert, 2004; Bruce, 2006; Prior, 2006; Rectanus, 2006; Featherstone, 2007): 
- Additional spaces (places such as cafés, restaurants, museum stores, libraries, movie theatres, etc.)

- Organisation of special events (income-generating activities that align with the concepts and spatial characteristics of the museum)

- Fulfilment of diverse visitor expectations (such as allowing visitors to participate in activities, offering entertainment and fiction, carrying out projects that encourage social interaction, etc.)

- Different exhibition techniques and spaces (including chronological as well as thematic exhibitions, digital exhibition techniques, flexible use of exhibition spaces, etc.)

- Differentiating collections (including objects that allow for visitor interaction and that are not only related to the past but the present and future as well)

- Acceptance of sponsorships

- Existence of branches

- Professional use of social media

This evaluation process resulted in a total of 12 museums identified as having postmodern characteristics: Museum of the Princes' Islands, Sadberk Hanım Museum, Yapi Kredi Vedat Nedim Tor Museum, Istanbul Toy Museum, Turkey Isbank Museum, Pera Museum, The Museum of Santral Energy and Modern Arts, the Museum of Innocence, Miniatürk Mini Park of Turkey, Rahmi M. Koc Museum, Sakip Sabanci Museum and Istanbul Museum of Modern Art.

\section{Data collection}

This study used a standardised interview guide and employed semistructured interviews to collect data. In order to finalise the data collection instrument, four experts and a researcher specialised in qualitative research were approached, and the question form was re-evaluated. Finally, five questions about postmodern conditions in museums' marketing practices were included along with four questions about the respondents. The first question asked respondents what they thought about museum practices that cause an instantaneous rupture in visitors' relationship with reality, moving them to another dimension in time and space. The second question asked what they thought about juxtapositions of opposites in the interior and exterior architectures, exhibition spaces or collections of museums. The third question asked them about their views on museum practices that turn audiences into active participants by acting as an intermediary between visitors and the experience. The fourth question aimed to uncover respondents' thoughts about museum practices that transform visitors from 
consumers to prosumers. Finally, the interviewees were asked what they think about museum practices that allow visitors to participate in multiple types of activities (i.e. social, recreational, educational) at the same time. Necessary follow-up questions were also administered during the interviews.

An appointment list containing interviewees' names and contact information was formed. In order to create this list, a letter explaining the study was mailed electronically to potential participants. Each participant was also telephoned, and the participants who voluntarily agreed to participate in the study were included. The interview time and places were determined by the participants. For two of the museums, two respondents participated, and two interviews were conducted. Thus, a total of 14 interviews were conducted face-to-face in Turkish between $12^{\text {th }}$ July and $19^{\text {th }}$ August 2016, lasting anywhere from 45 minutes to 1 hour 32 minutes. Interviews were conducted in museum facilities such as cafés, restaurants, libraries, gardens and offices, and they were recorded with the permission of interviewees. Anonymity was ensured by assigning each participant a respondent number (R1 to R14).

\section{Data analysis}

A deductive approach was used to develop categories based on similar themes, patterns, concepts and features that appeared among responses (Neuman, 2006), and the data were analysed descriptively. Descriptive analysis helps researchers to develop a framework for the organisation and interpretation of the data. This analysis is comprised of three steps: data processing according to a thematic framework, identification of findings and interpretation of findings. Computer-aided qualitative data analysis software NVivo 11 was used to code all interview transcripts. Each postmodern condition that influences the marketing of postmodern museums - decentered subject, reversal of production and consumption, fragmentation, juxtaposition of opposites and hyperreality - was considered a theme and analysed separately.

In order to prepare the data for analysis, recordings were first transcribed by the researchers, helping them to develop a comprehensive understanding of the data (Patton, 2002). These transcriptions were sent to and verified by the interviewees. Macro-analysis was conducted to ascertain the general structure of the data set. Strategies suggested by Creswell (2013) were adopted to ensure the reliability of data. Creswell (2013) recommends that the data should undergo at least two procedures 
out of the eight he outlines. First, this study used participant approval or member checking. The transcripts were sent back to each participant to ensure that their thoughts were represented correctly and accurately. Analyses were then conducted on the basis of the controlled texts. Second, peer review or debriefing was used as a second reliability control. This required an external check of the research process - especially of its methods - by the peer debriefer (Creswell, 2013, p. 251). The data were thus analysed by two researchers experienced in the field of qualitative research. Randomly selected codes from two interviewees' responses were sent to experts who were asked to code the data and determine the themes and categories. Their results were then cross-checked with the researchers' results. The discrepancies between the experts' and researchers' analyses were solved, and, where necessary, researchers used the codes provided by the experts. In this vein, the data were controlled by participating experts as well.

\section{RESULTS}

The number of female respondents in this sample was relatively high (12 interviewees). Analysis of the respondents' professions clearly showed that they occupied mostly managerial positions. Furthermore, some respondents were found to be responsible for programming and marketing. Only one respondent had a degree in museology (see Appendix 1). Although some respondents had worked in museums for up to 33 years, most had 1-2 years of experience in their current workplace.

\section{Decentered subject}

The subject in the postmodern era has lost control of the environment in which he or she lives and seeks alternate experiences. Thus, the subject is relegated to the periphery of his or her experience and occupies a passive position, as commodities appear to become the producers of benefits for individuals who follow instructions correctly (Van Raaij, 1993). One of the best examples of the decentred subject in a postmodern museum is the After Dark project initiated by the Tate Britain museum in 2014. This project offered a unique, distinctive virtual experience for visitors; robots in the museum replaced the visitors at night, allowing subjects to tour the museum after dark through their eyes (After Dark, 2014).

When respondents were asked whether their museum implemented any approaches or applications intended to change consumers' attitudes 
towards their reality via the museum offerings, most of them expressed that they offered digital applications with which to enrich visitors' experiences. One of the participants (R11) underlined the importance and impact of information technologies, noting that:

"We have virtual visitors interested in our museum. The use of such technologies would be great for the museums."

R1 commented on the accessibility of museum experts and underlined the importance of information technologies in this regard:

"Indeed, scientists or researchers may wish to see an artwork, or examine it, and they may not always have the time to visit. Or, they may not see the artwork in the depot. Therefore, such a chance can be offered to them."

The participants agreed that the use of technologies diminishes the limitations of geographic distance, as in the case of the After Dark project. However, apart from the cited advantages, R1 underscored the importance of visiting the physical museum site:

"For example, in the Google Art Project (...) they have a technology called gigapixel. You can zoom right in and examine the details that you could never see in the museum. However, digital display does not offer you the possibility of being in the same space and atmosphere with the artwork. Being there and feeling the atmosphere is something unique that you cannot experience otherwise."

Advocating for the uniqueness of the museum experience, R8 claimed that:

"Naturally, we expect people to visit the museum personally. You can offer an experience with technology, cameras or surveillance, but they do not guarantee visitor satisfaction. In museums, you can touch, see and live it directly. Virtually, we offer that option, but you cannot feel the same excitement."

The responses of participants showed that some museums opposed the decentered subject. However, R7 postulated that these technologies and robots actually promote increased museum visitation:

"... seeing the artwork[s] on the net and experiencing them personally by visiting the museum are different things. Lately, we were talking about the Van Gogh Museum in Amsterdam. People can see the artwork of Van Gogh in every detail, in high resolution, through the Google Cultural Institute Project. But the museum is one of the busiest, with long lines at the gate-because people want to go and visit the museum." 
Study results showed that participants generally held negative attitudes towards the decentered subject and still attached importance to subjects physically visiting museums. Furthermore, they did not appreciate any intermediaries between the artworks and the visitors.

\section{Reversal of production and consumption}

Postmodernism argues that production and consumption cannot be considered separate from one another. Neither production nor consumption is superior to the other, as production continues throughout the consumption process. Consequently, postmodern consumers adhere to a cyclical process in which each act of consumption is considered an act of production and vice versa (Firat \& Venkatesh, 1993). For example, virtual visitors to the Rijksmuseum can create their own individual collections after responding to a few questionnaires on the Master Matcherpage when they become members of the Rijks studio section of the museum's website. They can then share this collection on social media. Visitors' collections include t-shirt prints, mobile phone covers, wallpaper patterns and so on (Rijks Museum, 2020). Museum managers were asked whether they implemented similar practices or projects to those of the Rijksmuseum. Noting that they practised similar operations in their museum, R4 stated:

"For example, we have notebooks with the boxes (in the museum) on their covers. It may be an enjoyable experience for the visitors to design their own notebooks with the covers they choose. ... People also discovered an incredible number of visuals from different angles and many other discoveries. Offering them the possibility to produce something special makes them more active and willing."

Providing another example from a different museum, R14 explained:

"They produce embroidery of a painting - buying the fabric, needle and thread and stitching the picture onto the fabric at home."

However, she warned that this can become tricky and noted that it should be handled with caution. In a similar vein, R3 tried to explain their understanding of production:

"... it can be degenerated. It may be something lowering. But, for example, there is the Venus of Boticelli. It is a beautiful female figurine. I have seen it in London, England. They organised an exhibition: Inspirations of Venus. They have collected all the imitations inspired by Botticelli's Venus. Those artworks were reproduced, but the artists also included their own interpretation, not like the original one. (...) On the other hand, museum production is just for personal use, including no labour, no creativity, something industrial..." 
Here, R3 stressed the importance of practices that require visitors' creativity and labour as opposed to the simple reproduction of the artefact. She advocated for processes whereby visitors are converted into productive consumers.

\section{Fragmentation}

The condition of fragmentation focuses on fragmented experiences, such as social, recreational and educational experiences and the combinations thereof. Postmodern consumers desire fluid movements between these experiences (Firat \& Schultz, 1997; Davidson \& Sibley, 2011). One of the distinctions between modern and postmodern museums is the hosting of special events in postmodern museums, as well as the presence of additional spaces that emphasise the fragmentation of the museum. Participants exemplified several cases of special events in their museums. For example, R11 reported that:

"... Yoga and Dance classes were organised in the garden of the museum, and these classes continued for years. Some concerts were also organised. The Island Chorus, for example... or the Büyükada [the biggest of the Princes' Islands in Istanbul] Chorus... bands, musicians, and jazz concerts are among the popular events that take place in museum programs."

Noting the existence of similar events in their museum, R10 supplied the example below:

"We have book-reading days, hope you have heard. ... Every Tuesday, book enthusiasts gather here, and they discuss a book that they chose earlier, as well as having hot drinks and biscuits. Besides this, we organise an interactive museum and workshops for kids."

R14 described how their museum offers open-air film shows for its visitors. She recounted a detailed account of the program they organised:

"We wanted to organise something different, an open-air film night, for example. We will show old films -old-fashioned ones. We will start with Frank Sinatra and Grace Kelly's High Society. The show will be over at 23:00. The museum will be open between 23:00 and 00:00. People will visit the museum at night."

Another example R14 supplied related to nature and spanned a variety of activities:

"In our summer school, we use the garden, which is an extension of Emirgan Grove. Art and nature, together... Kids first set up their own tents and then meet each other. They learn how to make knots. They learn about trees. Then, they read 
tales. After reading tales and stories, they start drawing and painting pictures. Nature, tales and pictures - they learn to act together. Then, the kids go to the museum and see the exhibition. They leave the museum creating something of their own."

As the findings suggest, several postmodern museums offer a wide array of opportunities for dining, music, film shows, sports, dancing, reading, camping and more, as well as combinations of these activities. Certainly, all these events or activities basically cover museum visits.

\section{Juxtaposition of opposites}

Postmodernism posits that oppositions such as global versus local, past versus present and culture versus trade constitute interpenetrations that postmodern consumers accept willingly (Firat \& Venkatesh, 1993; Firat \& Dholakia, 2006). Thus, postmodern museums endorse the unrestricted existence of oppositions rather than attempting to reconcile them. Accordingly, R3 expressed that these oppositions are desirable when it comes to displays:

"Side-by-side display of remnants of daily life from an ancient civilisation and artworks produced by contemporary artists' inspiration and perception reveals a continuity. For example, we tried to narrate the perception of Anatolian goddesses in the Mysterious Women of the Bronze Age exhibition via modern artworks that we ordered from contemporary artists, and we also gathered the artists at the exhibition. It was the continuity of one into another, as well as contemporary reflections."

Similarly, R5 explained another example of a display in which the lives of the past were portrayed through the lens of the contemporary era:

"Coffee Break: The Adventure of Coffee in Kütahya Tiles and Ceramics exhibition... We positioned traditional teahouses as the preliminary social media of the Ottoman period. We presented those teahouses as places that belong to daily life in which people meet, chat and socialise. As Kütahya tiles and ceramics seem to be old-fashioned objects for our generation, this exhibition approximates them to daily life via coffee flavour and the voices of teahouses."

Along this line of thinking, R10 attributed the reciprocity of the past and present to the use of technology and explained her thoughts:

"Similar things do happen in all museums. In fact, an intensive opposition does exist; for example, over there we see anancestor of film projectors, the Laterna Magica, and when you glance left, you see a DVD player and a screen. For me, this also represents opposition, but museums should have such opposites together." 
Among the participants, R13 believed that their museum's architectural structure was a good example of juxtaposition of opposites and claimed that this juxtaposition was created by the dichotomy of past and present. She explained her argument:

"When you look inside, everything original is in its own colour. And the new buildings are in the brownish painted areas. Why? To specifically show that they are new. None of the buildings in this complex is coincidentally grey or brown. I mean, opposites were planned as old and new buildings."

These findings suggest that juxtaposition of opposites may vary from museum to museum, but the most prominent contradiction museums present is the dichotomy between the past and present.

\section{Hyperreality}

Over time, hyperreality transforms objects into signs. With the shift in value from use and exchange value to sign value, the commodity has lost all necessary cohesion with the real. Initially, the real object becomes a sign; this is the simulation stage. In subsequent stages, the sign becomes an object again, but not a real object - an object even further removed from the real than the sign itself. In other words, postmodern objects are conceived with their reproducibility in mind (Koch \& Elmore, 2006).

Hyperreality is expressed as the blurring of distinctions between reality and fiction. Postmodern consumers often prefer replicas to originals, place importance on nostalgic experiences and feel happier within manufactured worlds (Firat \& Shultz, 1997). Therefore, whether the museum experience is based on reality or fiction is unimportant, as individuals' experiences are the priority. The participants were asked whether their museums offer an instantaneous rupture in visitors' relationships with reality and moved them to another dimension in time and space. R8 described an application in their museum, a helicopter simulation, in detail:

"We guide people to Istanbul; they board a helicopter and start seeing the city from the air. They then land at the Blue Mosque and enter it via the ablution fountains. They also see the interior of the mosque. After leaving the mosque, they go to Hagia Sophia, then to the Topkapi Palace. In this way, you see the historical heritage of Istanbul from the air, and you also visit interiors. Here, we offer people something they cannot achieve in their real lives. All this is condensed into a 13-14-minute film." 
The researchers personally tested this helicopter simulation, experiencing ascents, descents and horizontal shifts as if in the actual vehicle. When the helicopter dives into a cave, visitors see threedimensional bats while water is sprayed onto their feet. Similarly, water is sprayed on visitors' heads when the helicopter descends below clouds. In this way, visitors enter a new dimension of time and space.

R14 recalled a visit she made to a museum in which she saw a film of a primitive man running on snow. To achieve a feeling of reality, the temperature of the room was reduced. According to R14, this kind of hyperreality was also created in an exhibition:

"There was an exhibition titled Across. There was a full-scale ship in the exhibit area. The exhibit was about the relations between Asia Minor and the Cyclades Islands. A replica of a ship, then the only vehicle for transportation, was built in the exhibition."

In the ship, there was a dark room in which visitors experienced a simulated storm at sea. In this way, visitors were transported from the real world.

These results suggest that digital technologies in museums often emerge as an easy solution for the realisation of hyperreality. Aside from digital technologies, hyperreality was also created by the provision of fiction in the museum.

\section{DISCUSSION AND CONCLUSIONS}

This study aimed to explore the ways in which museum marketing meets postmodern conditions. The dynamic structures of the market and the limitations of existing marketing theories justify the need for the current study (Brown, 1993). Specifically, the findings of the study provide evidence that museums have acquired postmodern qualities in the postmodern era. Consequently, the marketing of postmodern museums differs from that of modern museums. Theories suggest that postmodern marketing consists of five basic conditions (Firat, 1991; Firat et al., 1995; Firat \& Venkatesh, 1996; Firat \& Shultz, 1997, 2001; Venkatesh, 1999; Firat \& Dholakia, 2006): decentered subject, reversal of production and consumption, fragmentation, juxtaposition of opposites and hyperreality.

The findings of this study show that museums oppose the idea of the decentered subject, claiming that it pacifies the visitors. Museum staff 
members, staunchly underscoring the importance of visitors' physical presence in the museum, oppose any and all applications that could obstruct interactions between a museum and its visitors. This finding aligns with the findings of a study by Antón et al. (2018), which demonstrates the importance of onsite museum experience. The current study's findings suggest that visitor experience is unique and that subject should actively participate in the experience in order to maximise their rewards. Potential customers who are unable to visit a museum due to geographic distance, as well as those who want to experience the museum in an alternative way, cannot be ignored, and the needs of this market must not be neglected. However, museum managers should also consider the risks that hindrances to visitors' participation in onsite experiences and co-production pose.

Additionally, this study finds that museums should focus on specific issues in order to transform museum visitors into producing consumers. As such, production should not be limited to reproductions of artwork, which may damage the image of the museum. Rather, production should allow visitors to employ their creativity, imagination and labour. Even the most perfect reproduction of a museum object lacks temporal and spatial context. This study's findings reveal the importance of the incorporation of visitors' labour and creativity into production as opposed to the more aesthetic concerns of modern-era production. With this in mind, criticisms of the culture industry must be considered in the reversal of production and consumption in order to impede kitsch production and meta-fetishism (Koch \& Elmore, 2006; Benjamin, 2008; Ward, 2014). Moreover, museum managers should strive to find creative ways for their guests to involve themselves in production and consumption simultaneously.

Findings also reveal that most of the museums sampled offer visitors a variety of experiences, such as dining, music shows, film screenings, sports, dance lessons, reading, camping and several others. Postmodern museum visitors want to do more than just attend cultural events and institutions. They enjoy and become accustomed to participatory learning and entertainment experiences - the exact reverse of the traditional spectacle (Bennett, 1994; Simon, 2010). Additional spaces and the allocation of special events are evidence of fragmentation within the postmodern museum. It is widely accepted that visitors to postmodern museums are searching for fragmented moments in liquid time. This fact also highlights visitors' desire to experience a combination of social, recreational and educational activities at once, as suggested by Davidson and Sibley (2011). For this reason, museums offer a combination of events and activities to their visitors in their additional spaces. However, it is vital for the museums 
to focus on the quality of these events and activities in order to achieve a competitive edge in the market.

Findings also identify several juxtapositions of opposites in museums. These opposites occur in various forms, such as the architectural structures of the buildings, the contents of museums' collections and the ways in which these collections are displayed. The juxtaposition of past and present is the most common juxtaposition found in museums, a finding that is supported by previous research (Schubert, 2004). One-third of the participating museums in this study use the Google Cultural Institute Project, which offers museum visitors the opportunity to choose artworks freely and make their own collections. Furthermore, this opportunity signifies eclecticism, which is the most prominent consequence of the juxtaposition of events (Caines, 2013; Kahraman, 2015). Moreover, participation in the Google Cultural Institute Project offers an opportunity for both modern and postmodern museums to be perceived by visitors as appreciative of the juxtaposition of opposites. Positioning the architecture or the objects in their collection in a way that highlights these oppositions may inspire curiosity among visitors and motivate them to visit the museum repeatedly. Postmodern museums can also use opposites in architecture, exhibition spaces and collections to surprise and even shock their visitors.

Finally, this study's findings underline the dominance of digitalisation in the context of generating hyperreality. Digitalisation encapsulates experiences of augmented reality, virtual reality, simulations and similar digital elements, thus providing visitors with an experience detached from time and space. In fact, hyperreality is a term that denotes objects or experiences that appear more real than reality. The use of virtual reality and the alteration of perceptions via sensors and similar technologies in real space (Schweibenz, 2004; Rancati et al., 2016) indicate the existence of hyperreality in museums. In fact, all assets of museums (e.g. architecture, collections, exhibitions and displays) that provide a rupture from reality can be regarded as hyperreality. However, it should be noted that a modern museum cannot be considered postmodern based on the presence of digitalisation and provision of hyperreality alone.

\section{Limitations}

The results of the present study should be evaluated in light of certain limitations. The primary limitation of the study is that only 12 museums exhibiting postmodern characteristics in Istanbul, Turkey were examined. 
Several museums in other parts of the country may have postmodern characteristics or at least occasionally display postmodern attitudes and practices. It is possible that inclusion of other museums in other parts of the country may strengthen the findings of this study. Although qualitative studies allow researchers to understand the attitudes, behaviours and perceptions of museum managers, the need for comprehensive studies is apparent. Therefore, future research should develop and validate a mixed data collection method with which to enrich our understanding of postmodern museums.

Moreover, this study is limited to museum managers as participants, and their accounts of museum practices serve merely as a starting point for further research into the effects of postmodern conditions on museum marketing. However, understanding how visitors evaluate these practices and how they position the museums they visit is essential. Therefore, continued examination of visitors' perspectives regarding postmodern museum practices has the potential to deepen our understanding of postmodern museums.

\section{REFERENCES}

After Dark (2014). IK Prize 2014: After Dark. Retrieved 2 December, 2020, from http://www.tate.org.uk/whats-on/tate-britain/special-event/ik-prize-2014-afterdark .

Amine, L. S., \& Smith, A. J. (2009). Challenges to modern consumer segmentation in a changing world: The need for a second step. Multinational Business Review, 17(3), 71-100.

Antón, C., Camarero, C., \& Garrido, M. J. (2018). What to do after visiting a museum? From post-consumption evaluation to intensification and online content generation. Journal of Travel Research, 58(6), 1052-1063. Doi: 10.1177/0047287518793040.

Artan, E. C. (2014). Bugün her zamankinden daha çekici: Müzeler ve popüler kültür. GençSanat, 228, 28-35.

Baker, S. (2017). Identifying behaviors that generate positive interactions between science museums and people on Twitter. Museum Management and Curatorship, 32(2), 144159.

Barrett, J. (2011). Museums and the public sphere. United Kingdom: Wiley-Blackwell.

Belenioti, Z. C., \& Vassiliadis, C. A. (2017). Branding in the new museum era. In A. Kavoura, D. P. Sakas, \& P. Tomaras (Eds.), Strategic innovative marketing (pp. 115121). Switzerland: Springer.

Benjamin, W. (2008). The work of art in the age of mechanical reproduction. UK: Penguin.

Bennett, T. (1994). The exhibitionary complex. In N. B. Dirks, G. Eley and S. B. Ortner (Eds.), Culture/Power/History: A reader in contemporary social theory (pp. 123-154). Princeton University Press.

Brown, S. (1993). Postmodern marketing?. European Journal of Marketing, 27(4), 19-34.

Brown, S. (1995). Postmodern marketing. London: Routledge. 
Bruce, C. (2006). Spectacle and democracy: Experience music project as a post-museum. In J. Marstine (Ed.), New museum theory and practice: An introduction (pp. 129-151). UK: Blackwell.

Caines, M. (2013, 3 November). Arts Head: Amit Sood, Director, Google Cultural Institute. Retrieved 2 December, 2020, from The Guardian web site: https://www.theguardian.com/culture-professionals-network/cultureprofessionals-blog/2013/dec/03/amit-sood-google-cultural-institute-art-project.

Cerquetti, M. (2016). More is better! Current issues and challenges for museum audience development: A literature review. Journal of Cultural Management $\mathcal{E}$ Policy, 6(1), 3043.

Chhabra, D. (2008). Positioning museums on an authenticity continuum. Annals of Tourism Research, 35(2), 427-447.

Cova, B., \& Cova, V. (2001). Tribal aspects of postmodern consumption research: The case of French in-line roller skaters. Journal of Consumer Behaviour, 1(1), 67-76.

Creswell, J. W. (2013). Qualitative inquiry and research design: Choosing among five approaches. (3rd ed.). USA: Sage Publications.

Davidson, L., \& Sibley, P. (2011). Audiences at the "new" museum: Visitor commitment, diversity and leisure at the Museum of New Zealand Te Papa Tongarewa. Visitor Studies, 14(2), 176-194.

Dawson, E., \& Jensen, E. (2011). Towards a contextual turn in visitor studies: evaluating visitor segmentation and identity-related motivations. Visitor Studies, 14(2), 127140.

Denzin, N. K., \& Lincoln, Y. S. (2005). The Sage handbook of qualitative research. California: Sage Publications Ltd.

Doltas, D. (2003). Postmodernizm ve eleştirisi: Tartışmalar uygulamalar. Ankara: İnkılap.

Drotner, K., \& Schrøder, K. C. (Eds.) (2013). Museum communication and social media: The connected museum. New York: Routledge.

Duclos, R. (1994). Postmodern/postmuseum: New directions in contemporary museological critique. Museological Review, 1(1), 1-13.

Featherstone, M. (2007). Consumer culture and postmodernism (2nd ed.). Great Britain: Sage Publications.

Firat, A. F. (1991). The consumer in postmodernity. In R. H. Holman \& M. R. Solomon (Eds.), Advances in Consumer Research Volume 18 (pp. 70-76). Utah: Association for Consumer Research.

Firat, A. F., \& Dholakia, N. (2006). Theoretical and philosophical implications of postmodern debates: Some challenges to modern marketing. Marketing Theory, 6(2), 123-162.

Firat, A. F., Dholakia, N., \& Venkatesh, A. (1995). Marketing in a postmodern world. European Journal of Marketing, 29(1), 40-56.

Firat, A. F., \& Shultz, C. J. (1997). From segmentation to fragmentation: Markets and marketing strategy in the postmodern era. European Journal of Marketing, 31(3/4), 183-207.

Firat, A. F., \& Shultz, C. J. (2001). Preliminary metric investigations into the nature of the 'postmodern consumer'. Marketing Letters, 12(2), 189-203.

Firat, A. F., \& Venkatesh, A. (1993). Postmodernity: The age of marketing. International Journal of Research in Marketing, 10(3), 227-249.

Firat, A. F., \& Venkatesh, A. (1995). Liberatory postmodernism and the reenchantment of consumption. Journal of Consumer Research, 22(3), 239-267. 
Firat, A. F., \& Venkatesh, A. (1996). Postmodern perspectives on consumption. In R. W. Belk, N. Dholakia, \& A. Venkatesh (Eds.), Consumption and marketing, macro dimensions (pp. 234-265). USA: South-Western College Publishing.

Foucault, M., \& Miskowiec, J. (1986). Of other spaces. Diatritics, 16(1), 22-27.

Giebelhausen, M. (2006). Museum architecture: A brief history. In S. Macdonald (Ed.), A companion to museum studies (pp. 223-244). United Kingdom: Wiley-Blackwell.

Gilmore, A., \& Rentschler, R. (2002). Changes in museum management: A custodial or marketing emphasis?. Journal of Management Development, 21(10), 745-760.

Glaser, J. R., \& Zenetou, A. A. (1996). Museums - yesterday and today. In J. R. Glaser \& A. A. Zenetou (Eds.), Museums: A place to work: Planning museum careers (pp. 10-30). London: Routledge.

Grant, P. S., Bal, A. \& Parent, M. (2012). Operatic flash mob: Consumer arousal, connectedness and emotion. Journal of Consumer Behaviour, 11(3), 244-251.

Harvey, D. (1991). The condition of postmodernity: An enquiry in to the origins of cultural change. London: Wiley-Blackwell.

Heath, C., \& Vom Lehn, D. (2008). Configuring 'interactivity' enhancing engagement in science centres and museums. Social Studies of Science, 38(1), 63-91.

Hemp, P. (2006). Avatar-based marketing. Harvard Business Review, 84(6), 48-57.

Hooper-Greenhill, E. (2007). Museums and education: Purpose, pedagogy, performance. London: Routledge.

Huyssen, A. (1995). Twilight memories marking time in a culture of amnesia. New York: Routledge.

International Council of Museums (ICOM) (2019). Museum Definition. Retrieved 2 December, 2020, from https://icom.museum/en/resources/standardsguidelines/museum-definition/.

Jafari, A., Taheri, B., \& Vom Lehn, D. (2013). Cultural consumption, interactive sociality, and the museum. Journal of Marketing Management, 29(15-16), 1729-1752.

Kahraman, H. B. (2015). Bakmak görmek bir de bilmek. İstanbul: Kapı Yayınları.

Kasim, A., Cetinel, F. G., \& Yolal, M. (2014). Museums? Evidence from two countries. Almatourism-Journal of Tourism, Culture and Territorial Development, 5(10), 23-37.

Keene, S. (2005). Can museums survive the postmodern?. Archaeology International, 9, 3639.

Koch, A. M., \& Elmore, R. (2006). Simulation and symbolic exchange: Jean Baudrillard's augmentation of Marx's theory of value. Politics \& Policy, 34(3), 556-575.

Komarac, T., Ozretic-Dosen, D., \& Skare, V. (2017) Understanding competition and service offer in museum marketing. Academia Revista Latinoamericana de Administración, 30(2), 215-230.

Kotler, N. (2001). New ways of experiencing culture: the role of museums and marketing implications. Museum Management and Curatorship, 19(4), 417-425.

Kotler, N., \& Kotler, P. (2000). Can museums be all things to all people?: Missions, goals, and marketing's role. Museum Management and Curatorship, 18(3), 271-287.

Kotler, N. G., Kotler, P., \& Kotler, W. I. (2008). Museum marketing and strategy: Designing missions, building audiences, generating revenue and resources (2nd ed.). San Francisco: Wiley-Blackwell.

Lepouras, G. \& Vassilakis, C. (2004). Virtual museums for all: employing game technology for edutainment. Virtual Reality, 8(2), 96-106.

Lumley, R. (2003). The museum time machine: Putting cultures on display. New York: Routledge. 
Lyotard, J. F. (2013). Postmodern durum (İ. Birkan, Trans.). İstanbul: Bilgesu Yayıncilık. (Original work 1967).

McLean, F. (1995). A marketing revolution in museums?. Journal of Marketing Management, 11(6), 601-616.

Message, K. (2006). The new museum. Theory, Culture and Society, 23(2-3), 603-606.

Neuman, W. L. (2006). Social research methods: Qualitative and quantitative approaches (6th ed.). Boston: Pearson Education.

Nooteboom, B. (1992). A postmodern philosophy of markets. International Studies of Management \& Organization, 22(2), 53-76.

Odabasi, Y. (2014). Postmodern pazarlama (4th ed.). İstanbul: Media Cat.

Packer, J., \& Ballantyne, R. (2016). Conceptualizing the visitor experience: A review of literature and development of a multifaceted model. Visitor Studies, 19(2), 128-143.

Patton, M. Q. (2002). Qualitative research and evaluation methods. California: Sage Publications.

Prentice, R. (2001). Experiential cultural tourism: Museums \& the marketing of the new romanticism of evoked authenticity. Museum Management and Curatorship, 19(1), 526.

Prior, N. (2006). Postmodern restructurings. In S. Macdonald (Ed.), A companion to museum studies (pp. 509-524). UK: Blackwell.

Pulh, M., \& Mencarelli, R. (2015). Web 2.0: Is the museum-visitor relationship being redefined?. International Journal of Arts Management, 18(1), 43-51.

Pulh, M., Marteaux, S., \& Mencarelli, R. (2008). Positioning strategies of cultural institutions: A renewal of the offer in the face of shifting consumer trends. International Journal of Arts Management, 4-20.

Rancati, E., Scuotto, V., Codignola, F., \& Gordini, N. (2016). Augmented Reality for Enhancing the Customer Experience in Museums: An Exploratory Analysis. Retrieved May, 2017, from 18. Toulon-Verona International Conference web site: https://sites.les.univr.it/eisic/index.php/conference-proceedings-2/.

Rectanus, M. W. (2006). Globalization: Incorporating the museum. In S. Macdonald (Ed.), A companion to museum studies (pp. 381-397). UK: Blackwell.

Rentschler, R. (1998). Museum and performing arts marketing: A climate of change. The Journal of Arts Management, Law, and Society, 28(1), 83-96.

Rentschler, R., \& Gilmore, A. (2002). Museums: Discovering services marketing. International Journal of Arts Management, 5(1), 62-72.

Rijks Museum (2020). Master Matcher. Retrieved 2 December, 2020, from Rijks Museum web site: www.rijksmuseum.nl/en/mastermatcher.

Ritzer, G. (2010) Focusing on the prosumer. In B. Blättel-Mink \& K. U. Hellmann (Eds.), Prosumer revisited (pp 61-79). Germany: VS Verlag für Sozialwissenschaften.

Ritzer, G. (2014). Prosumption: Evolution, revolution, or eternal return of the same? Journal of Consumer Culture, 14(1), 3-24.

Rosenau, P. M. (1991). Post-modernism and the social sciences: Insights, inroads, and intrusions. Princeton University Press.

Russo, A. \& Watkins, J. (2005). Post-museum experiences: Structured methods for audience engagement. In H. Thwaites (Ed.), Proceedings of the eleventh international conference on virtual systems and multimedia (pp. 173-182). Belgium. Retrieved 2 December, 2020, from https://eprints.qut.edu.au/3985/1/3985_1.pdf.

Schubert, K. (2004). Küratörün yumurtası: Müze kavramının Fransız İhtilalinden günümüze kadar olan evrimi (R. Smith, Trans.). İstanbul: İstanbul Sanat Müzesi Vakfı Yayınları. (Original work published 2000). 
Schweibenz, W. (2004). Virtual museums: The development of virtual museums. ICOM News Magazine, 3, 3.

Scoffield, S., \& Liu, J. (2014). Online marketing communications and the postmodern consumer in the museum context. Retrieved 2 December, 2020, from Cambridge University, Cambridge Business \& Economics Conference (CBEC) web site: http://www.gcbe.us/2014_CBEC/data/Susan\%20Scoffield,\%20Jie\%20Liu.pdf.

Simon, N. (2010). The participatory museum. California: Museum 2.0.

Stanbridge, A. (2005). Display options. International Journal of Cultural Policy, 11(2), 157-170.

Taheri, B., O'Gorman, K., \& Baxter, I. (2016). Contemporary issues in museums and heritage marketing management: Introduction to the special issue. Journal of Marketing Management, 32(15-16), 1387-1391.

Tobelem, J. M. (1997). The marketing approach in museums. Museum Management and Curatorship, 16(4), 337-354.

Tufts, S., \& Milne, S. (1999). Museums: A supply-side perspective. Annals of Tourism Research, 26(3), 613-631.

Urry, J. (2002). The tourist gaze (2nd ed.). London: Sage Publications.

Van Raaij, W. F. (1993). Postmodern consumption: Architecture, art, and consumer behavior. In W. F. Van Raaij \& G. J. Bamossy (Eds.), E- European Advances in Consumer Research Volume 1 (pp. 550-558). Utah: Association for Consumer Research.

Venkatesh, A. (1999). Postmodernism perspectives for macromarketing: An inquiry into the global information and sign economy. Journal of Macromarketing, 19(2), 153-169.

Venkatesh, A., Sherry, J. F., \& Firat, A. F. (1993). Postmodernism and the marketing imaginary. International Journal of Research in Marketing, 10(3), 215-223.

Vicente-Mariño, M. (2014). Audience research methods: Facing the challenges of transforming audiences. In G. Patriarche, H. Bilandzic, J. L. Jensen, \& J. Jurišić (Eds.), Audience research methodologies between innovation and consolidation (pp. 3753). New York: Routledge.

Ward, G. (2014). Postmodernizmi anlamak (T. Göbekçin, Trans.). İstanbul: Optimist. (Original work 1997).

Wu, C. T. (2014). Kültürün özelleştirilmesi: 1980'ler sonrasında şirketlerin sanata müdahalesi (E. Soğancılar, Trans.). İstanbul: İletişim. (Original work 2002).

Yorke, D. A., \& Jones, R. R. (1984). Marketing and museums. European Journal of Marketing, 18(2), 90-99. 
Appendix 1. Profile of the respondents

\begin{tabular}{|c|c|c|c|c|c|c|}
\hline Respondent & Gender & Position & Undergraduate & Postgraduate & $\begin{array}{c}\text { Experience } \\
\text { in museums } \\
\text { (years) }\end{array}$ & $\begin{array}{c}\text { Total } \\
\text { experience } \\
\text { in museum } \\
\text { business } \\
\text { (years) }\end{array}$ \\
\hline R1 & Female & Museum expert & History of art & History of art & 22 & 22 \\
\hline $\mathbf{R} 2$ & Female & $\begin{array}{c}\text { Marketing } \\
\text { communication } \\
\text { manager }\end{array}$ & Sociology & $\begin{array}{l}\text { European } \\
\text { studies }\end{array}$ & 1 & 6 \\
\hline R3 & Female & Museum director & $\begin{array}{l}\text { Turkish and } \\
\text { Islamic arts }\end{array}$ & - & 30 & 33 \\
\hline R4 & Male & Museum director & Sociology & Theatre & 2 & 2 \\
\hline R5 & Female & $\begin{array}{l}\text { Communication } \\
\text { and events } \\
\text { manager }\end{array}$ & $\begin{array}{l}\text { International } \\
\text { affairs and } \\
\text { politics }\end{array}$ & - & 1 & 1 \\
\hline R6 & Female & $\begin{array}{l}\text { Education and } \\
\text { events manager }\end{array}$ & History & Museology & 1 & 11 \\
\hline R7 & Female & $\begin{array}{l}\text { Digital and social } \\
\text { media manager }\end{array}$ & Visual arts & - & 1 & 1 \\
\hline R8 & Male & $\begin{array}{l}\text { Operation } \\
\text { manager }\end{array}$ & $\begin{array}{c}\text { International } \\
\text { affairs }\end{array}$ & - & 13 & 13 \\
\hline R9 & Female & $\begin{array}{l}\text { Assistant } \\
\text { manager }\end{array}$ & $\begin{array}{c}\text { Communication } \\
\text { sciences }\end{array}$ & $\begin{array}{l}\text { Republican } \\
\text { history }\end{array}$ & 9 & 9 \\
\hline R10 & Female & $\begin{array}{c}\text { Public relations } \\
\text { expert }\end{array}$ & $\begin{array}{c}\text { Classical } \\
\text { archaeology }\end{array}$ & $x_{5}$ & 7 & 7 \\
\hline R11 & Female & Curator & History & - & 3 & 11 \\
\hline R12 & Female & $\begin{array}{c}\text { Marketing and } \\
\text { public relations } \\
\text { manager }\end{array}$ & History & $\begin{array}{l}\text { Communication } \\
\text { strategies and } \\
\text { public relations }\end{array}$ & 11 & 11 \\
\hline R13 & Female & $\begin{array}{l}\text { Museum } \\
\text { manager }\end{array}$ & Visual arts & 1 & 12 & 12 \\
\hline R14 & Female & $\begin{array}{c}\text { Marketing and } \\
\text { public relations } \\
\text { manager }\end{array}$ & $\begin{array}{l}\text { Communication } \\
\text { sciences }\end{array}$ & $\begin{array}{l}\text { Advertising and } \\
\text { promotion }\end{array}$ & 2 & 8 \\
\hline
\end{tabular}

